\title{
A novel role of Shc adaptor proteins in steroid hormone-regulated cancers
}

\section{Syed Mahfuzul Alam ${ }^{1 *}$, Mythilypriya Rajendran ${ }^{1 *}$, Shouqiang Ouyang ${ }^{1}$, Suresh Veeramani ${ }^{1}$, Li Zhang ${ }^{1}$ and Ming-Fong Lin ${ }^{1,2}$}

\author{
${ }^{1}$ Department of Biochemistry and Molecular Biology, College of Medicine, University of Nebraska Medical Center, 985870 Nebraska \\ Medical Center, Omaha, Nebraska 68198-5870, USA \\ ${ }^{2}$ Eppley Institute for Cancer Research, University of Nebraska Medical Center, Omaha, Nebraska 68198, USA \\ (Correspondence should be addressed to M-F Lin; Email: mlin@unmc.edu) \\ *S M Alam and M Rajendran contributed equally to this work
}

\begin{abstract}
Tyrosine phosphorylation plays a critical role in growth regulation, and its aberrant regulation can be involved in carcinogenesis. The association of Shc (Src homolog and collagen homolog) adaptor protein family members in tyrosine phosphorylation signaling pathway is well recognized. Shc adaptor proteins transmit activated tyrosine phosphorylation signaling that suggest their plausible role in growth regulation including carcinogenesis and metastasis. In parallel, by sharing a similar mechanism of carcinogenesis, the steroids are involved in the early stage of carcinogenesis as well as the regulation of cancer progression and metastatic processes. Recent evidence indicates a cross-talk between tyrosine phosphorylation signaling and steroid hormone action in epithelial cells, including prostate and breast cancer cells. Therefore, the members of Shc proteins may function as mediators between tyrosine phosphorylation and steroid signaling in steroid-regulated cell proliferation and carcinogenesis. In this communication, we discuss the novel roles of Shc proteins, specifically $\mathrm{p} 52^{\mathrm{Shc}}$ and $\mathrm{p} 66^{\mathrm{Shc}}$, in steroid hormone-regulated cancers and a novel molecular mechanism by which redox signaling induced by $\mathrm{p} 66^{\mathrm{Shc}}$ mediates steroid action via a non-genomic pathway. The $\mathrm{p} 66^{\mathrm{Shc}}$ protein may serve as an effective biomarker for predicting cancer prognosis as well as a useful target for treatment.
\end{abstract}

Endocrine-Related Cancer (2009) 16 1-16

\section{Introduction}

Cancers in steroid hormone-responsive tissues presently account for more than $35 \%$ in men and more than $40 \%$ in women of all newly diagnosed cancers in the United States (Henderson \& Feigelson 2000). Extensive research has clearly demonstrated that the abnormal changes in the levels, frequencies, and types of steroid hormones are important contributors to the development of major cancer types such as the cancers of the prostate (androgen, estrogen), testes (in utero estrogen), breast (estrogen, progesterone), ovary (FSH, estrogen, androgen), uterine endometrium (estrogen), and thyroid (TSH, estrogen; Henderson \& Feigelson 2000). Thus, many studies have been focused on the involvement of steroids in the regulation of tumor development, cancer cell proliferation, progression, and metastatic processes. It is now evident that either in the early stage of carcinogenesis or in the advanced metastatic phenotype, steroid hormone action goes far beyond the classical receptor-mediated gene regulation. These steroid hormone-related cancers may share common mechanisms of carcinogenesis, such as DNA damage/mutation as well as the elevated levels of various growth factors induced by the excess of steroids, leading to aberrant growth regulation (Dickson \& Lippman 1987, Dabrosin et al. 1997, Devanesan et al. 2001). Recent advances further indicate that these hormones could also induce rapid, non-genomic responses and a convoluted network of interactions with different intracellular signaling pathways. 


\section{Non-genomic actions by steroid hormones}

Numerous studies have demonstrated the non-genomic action of steroid hormones, including androgens and estrogens, in cellular processes such as cell proliferation and motility (Berridge et al. 1998). The most intriguing facts on the non-genomic nature of steroids are that the effects depend on their rapid response and insisting no direct binding of nuclear receptors to gene expression, i.e., seconds to minutes and their insensitivity to the inhibitors of transcription and translation and/or the antagonists of the classical intracellular steroid hormone receptors. The non-genomic effects of steroids could be mediated by multiple pathways, and are discussed briefly as follows.

\section{Direct and acute action of steroids}

Steroids may have direct action on target molecules independent of steroid receptors. One such effect, for example, is the direct binding and activation of protein kinase $\mathrm{C}(\mathrm{PKC})$ isoforms such as $\mathrm{PKC}_{\alpha}$ and $\mathrm{PKC}_{\delta}$ by aldosterone and $17 \beta$-estradiol $\left(\mathrm{E}_{2}\right)$ respectively via binding directly to their regulatory domains $\mathrm{C}_{2}$ that mediates calcium $\left(\mathrm{Ca}^{2+}\right)$ binding and results in the autophosphorylation of these kinases (Alzamora \& Harvey 2008). Furthermore, aldosterone and $E_{2}$ rapidly and directly stimulate phospholipase $\mathrm{A} 2\left(\mathrm{PLA}_{2}\right)$ and cyclooxygenase (COX), which also result in the rapid increase in intracellular $\left[\mathrm{Ca}^{2+}\right]_{\mathrm{i}}$ (Harvey et al. 2002). The other direct and acute effects of steroids are their rapid action on voltage-gated and calcium-activated ion channels. $E_{2}$ activates the calcium-activated potassium channels via binding directly to its regulatory $\beta$-subunit (Valverde et al. 1999). Testosterone rapidly activates ATP-sensitive $\mathrm{K}^{+}$channels $\left(\mathrm{K}_{\mathrm{ATP}}\right)$ via opening $\mathrm{K}_{\mathrm{ATP}}$ channels (Er et al. 2004) and inhibits the L-type and T-type calcium channels $\left(\mathrm{I}_{\mathrm{Ca}, \mathrm{L}}\right.$; Michels et al. 2006, Er et al. 2007).

\section{Rapid action of steroids involving classical intracellular steroid receptors}

Steroids may bind to the classical intracellular steroid receptors and activate the second messenger pathways such as c-Src kinase that rapidly stimulate the MAPK/ERK and PI3K/AKT kinase pathways (Migliaccio et al. 2000). Interestingly, an androgen receptor (AR)/Src/modulator of non-genomic action of estrogen receptor (MNAR) complex and the cooperative association of c-Src, estrogen receptors (ERs), and AR activates MAPK and c-Src kinase pathways respectively (Kousteni et al. 2001, Unni et al. 2004).
Estrogens on binding to ER $\alpha$ may also serve as a transcriptional co-activator activating several transcriptional factors, such as activator protein 1 (AP-1), nuclear factor kappa B (NF- $\kappa \mathrm{B})$, and SP-1 in a nongenomic manner (Ray et al. 1997, Jakacka et al. 2001, Safe 2001). Steroids can also activate cAMP-dependent protein kinase A (PKA) via the transmembrane sex hormone-binding globulin (SHBG) receptor in association with transmembrane G-protein-coupled receptor (GPCR; Fortunati 1999, Rosner et al. 1999). The activation of PKA via the induction of cAMP by SHBG is observed in both prostate and breast cancer cells (Fortunati et al. 1996, Nakhla et al. 1997).

\section{Rapid action of steroids involving non-classical membrane-bound steroid receptors}

Steroids may undergo non-genomic action by binding to distinct non-classical membrane-bound steroid receptors. Several reports have presumed the presence of androgen- and estrogen-binding sites in a number of cells (Benten et al. 1999a,b, Armen \& Gay 2000, Kampa et al. 2002). Interestingly, both the membrane androgen receptor (mAR) and the membrane ER (mER) are found to be associated with an integral membrane protein caveolin that facilitates the assembling of several signaling molecules, including phosphatidylinositol 3-kinase (PI3K), Ras, and Src kinase in their scaffold domain (Okamoto et al. 1998, Kim et al. 1999, Lu et al. 2001). Furthermore, mER perhaps exists as in a cytoplasmic pool and the rapid action requires their interaction with caveolin in association with MNAR, Shc and growth factor receptors, and striatin that translocated ER to the plasma membrane (Wong et al. 2002, Lu et al. 2004, Song et al. 2005).

\section{Rapid action of membrane steroid receptors involving GPCR}

The most preserved non-genomic action of steroid hormones is the rapid increase in intracellular calcium concentration $\left[\mathrm{Ca}^{2+}\right]$ mediated via GPCR that constitutes $\alpha-, \beta$-, and $\gamma$-subunits (Lieberherr \& Grosse 1994, Benten et al. 1998), which ultimately results in the rapid activation of MAPK/ERK and PI3K/AKT pathways, leading to the activation of PKC and PKA (Kelly et al. 1999, Estrada et al. 2003). The interaction of mAR with GPCR results in the dissociation of $\mathrm{G} \alpha$-subunit and the signal is transmitted from $\mathrm{G} \beta \gamma$ through the activation of effector molecules including c-Src, Raf, and phospholipase C (PLC; Pierce et al. 2002). GPCR itself may also serve as the membrane receptor, i.e., binding of $E_{2}$ to an orphan GPCR, termed 
GPR30, plays a critical role in the rapid signaling of $\mathrm{E}_{2}$-mediated stimulation of Ras-dependent MAPK activation through the phosphorylation of Shc (Luttrell et al. 1996).

Rapid action of membrane steroid receptors via trans-activation of growth factor receptors

The rapid non-genomic actions of membrane steroid receptors may function via trans-activation of the growth factor receptors (Levin 2005), and of all membrane steroid receptors, $\mathrm{mER}$ is the paramount and well studied. The phenomenon is further confirmed by the co-existence of endogenous membrane receptors, including AR and ER, G-proteins, GPCR, growth factor receptors (EGFR, IGFR), non-receptor tyrosine kinases (Src, Ras), and linker proteins such as MNAR and striatin in the plasma membrane termed as 'signalosomes' (Hammes \& Levin 2007). Alternatively, steroids may activate growth factor receptor kinase activity by inhibiting the regulatory phosphatases (Meng et al. 2000).

\section{Rapid non-transcriptional action of membrane steroid receptors}

The other non-genomic action of steroids involving membrane receptors is the non-transcriptional effects of these receptors that provoke the posttranslational amendments including phosphorylation. By regulating kinases and phosphatases, steroids influence the cell functions such as cell motility via modifying actin cytoskeleton (Kampa et al. 2002, Meyer \& Feldman 2002, Levin 2005).

\section{Rapid action of steroids on membrane fluidity}

Steroids may mediate the non-genomic fashion through changes in membrane flexibility. Androgens via interacting with phospholipids in the lipid bilayer decrease the membrane fluidity, and subsequently alter the function of $\mathrm{Na}^{+} / \mathrm{K}^{+}$and $\mathrm{Ca}^{2+}$ ATPase systems and also influence cellular adhesion and cell-cell interaction (Duval et al. 1983, Van Bömmel et al. 1987).

In summary, we propose that though the nongenomic actions of steroids are mediated through multiple pathways, both genomic and non-genomic effects are interlinked as non-genomic actions of steroids ultimately influencing at least one of the classical genomic-mediated transcriptional activities. Nevertheless, the molecular mechanisms of steroids, especially androgens and estrogens, in both the development and progression of human endocrinerelated cancers at the non-genomic levels need further investigations. Along with these observations, in this review, we emphasize a novel non-genomic action of steroids promoting various stages of carcinogenesis via Shc proteins.

\section{Cross-talk of tyrosine phosphorylation signaling and steroids in carcinogenesis}

Every step of carcinogenesis is essentially controlled by various growth factors and their receptors, either it is steroid regulated or not. Growth factors, including nerve growth factor (Engebraaten et al. 1993, Sachs et al. 1996), fibroblast growth factor (Mignatti et al. 1991, Engebraaten et al. 1993, Taylor et al. 1993), plateletderived growth factor (Engebraaten et al. 1993, Choudhury et al. 1997), epidermal growth factor (EGF; Engebraaten et al. 1993, Hamada et al. 1995), keratin growth factor (Sachs et al. 1996), hepatocyte growth factor (Pelicci et al. 1995, Sachs et al. 1996), interleukin 2 (Ratner et al. 1992), insulin, and insulin-like growth factors (Stracke et al. 1989) are known to be involved in regulating cell proliferation, motility, invasion, and/or migration of various cell types. The activated receptors triggered by growth factors, cytokines, or adhesion molecules facilitate the docking of Src homology 2 (SH2) and phosphotyrosine-binding (PTB) domaincontaining adaptor molecules that transduce signals via downstream intracellular cascades. Each of the receptors for the ligands described above activates the c-Src homology and collagen homolog (Shc) adaptor proteins for signal transduction, which suggests a conceivable role of the Shc proteins in various stages of carcinogenesis.

Recently, several lines of evidence indicate that Shc proteins mediate diverse biological activities; for example, they may mediate steroid actions other than serving as adaptors in tyrosine phosphorylation signaling. Since the role of Shc proteins in mediating tyrosine phosphorylation signaling and in regulating oxidative stress-induced apoptosis has received much attention (Migliaccio et al. 1997, 1999, Ravichandran 2001), in this communication, we will first briefly overview Shc proteins and then focus our efforts on discussing the novel roles of Shc proteins, specifically $\mathrm{p} 52^{\mathrm{Shc}}$ and $\mathrm{p} 66^{\mathrm{Shc}}$, in steroid-regulated cancers.

\section{Members of Shc family: structure and function in tyrosine phosphorylation signaling}

\section{Molecular structure of Shc isoforms}

Shc proteins were first cloned using an SH2-coding sequence as a probe, and the Shc family includes three 
isoforms with molecular masses of 46, 52 and $66 \mathrm{kDa}$, which are encoded by the same gene at chromosome 1q21 (Pelicci et al. 1992). A promoter in the first intron of Shc locus transcribes the mRNA of $\mathrm{p} 66^{\mathrm{Shc}}$, whereas an alternate promoter and splicing generates the other two Shc isoforms, i.e., $\mathrm{p} 46^{\text {Shc }}$ and $\mathrm{p} 52^{\text {Shc }}$ (Ventura et al. 2002). These three isoforms of Shc protein contain overlapping amino acid sequences that contribute to a $\mathrm{SH} 2$ domain at the $\mathrm{COOH}$-terminal and a PTB domain at the $\mathrm{NH}_{2}$-terminal, separated by a central region enriched in proline and glycine residues, i.e., collagen homology (CH1) domain (Ravichandran 2001), as shown in Fig. 1. The SH2 domain $(\sim 100$ amino acids) is the prototype for protein-protein interaction modules that mediate the formation of multiprotein complexes during signaling (Pawson \& Scott 1997, Yoshida et al. 2004). Structurally, p66 ${ }^{\text {Shc }}$ differs from $\mathrm{p} 52^{\text {Shc }}$ and $\mathrm{p} 46^{\text {Shc }}$ by virtue of its unique $\mathrm{NH}_{2}$-terminal, a 110-amino acid $\mathrm{CH}_{2}$ region, which is also rich in proline and glycine residues (Migliaccio et al. 1997).

\section{Subcellular localization of Shc isoforms}

p66 $6^{\text {Shc }}$ is expressed primarily in epithelial cells, while $\mathrm{p} 52^{\mathrm{Shc}}$ and $\mathrm{p} 46^{\mathrm{Shc}}$ are expressed ubiquitously (Migliaccio et al. 1997). Most of $\mathrm{p}^{\mathrm{Shc}}$ protein is distributed throughout the cytosol and a fraction of p66 ${ }^{\text {Shc }}$ localizes within the inner membrane and intermembrane spaces of mitochondria (Orsini et al. 2004, Ventura et al. 2004, Giorgio et al. 2005, Nemoto et al. 2006). $\mathrm{p} 46^{\text {Shc }}$ is found to be localized in the mitochondrial matrix (Orsini et al. 2004, Ventura et al. 2004, Nemoto et al. 2006). Unlike $\mathrm{p} 46^{\text {Shc }}$ and $\mathrm{p} 66^{\text {Shc }}$, $\mathrm{p} 52^{\text {Shc }}$ is translocated to the plasma membrane from cytosol upon stimulation by growth factors, e.g., EGF (Migliaccio et al. 1997).

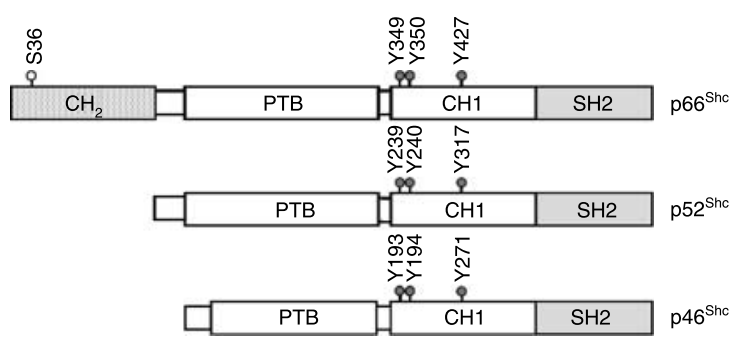

Figure 1 A schematic organization of Shc isoforms. The Shc proteins include three isoforms that are encoded by the same gene. They contain overlapping sequences. Three major tyrosine phosphorylation sites have been identified within the $\mathrm{CH} 1$ domain in all Shc isoforms. The unique $\mathrm{CH} 2$ domain of p66 ${ }^{\text {Shc }}$ isoform consists of 110 amino acids and contains a serine phosphorylation site (Ser-36). The PTB domain of $p 46^{\text {Shc }}$ is deficient of the first 46 amino acids.

\section{Shc isoforms in tyrosine phosphorylation signaling}

p46 $6^{\text {shc }}$

Shc proteins are expressed in distinct patterns and exhibit diverse biological functions. Ventura et al. (2004) have reported specifically $\mathrm{p} 46^{\text {Shc }}$ as the first example to be localized in the mitochondrial matrix by means of a mitochondrion-targeting signal, which is inactive in $\mathrm{p} 52^{\text {Shc }}$ and $\mathrm{p} 66^{\text {Shc }}$. Thus, $\mathrm{p} 46^{\text {Shc }}$ may play a role in the signal transduction pathways regulating mitochondrial physiology (Ventura et al. 2004). In addition to mediating tyrosine phosphorylation signaling (McGlade et al. 1992, Migliaccio et al. 1997), $\mathrm{p} 46^{\text {Shc }}$ may also modulate steroid action since steroids can regulate mitochondrial enzymatic activities (Ripple et al. 1997, 1999). Nevertheless, due to the limited studies on $\mathrm{p}^{\mathrm{Shc}}$ in steroid action in carcinogenesis, it will not be discussed further in this communication.

\section{$p 52^{\text {Shc }}$}

$\mathrm{p} 52^{\mathrm{Shc}}$ is responsible for transducing anchoragedependent growth signaling (Pelicci et al. 1992). In general, when cells are stimulated by growth factors, $\mathrm{p} 52^{\mathrm{Shc}}$ is recruited and binds to tyrosine kinase receptors through its $\mathrm{PTB}$ or $\mathrm{SH} 2$ domain, leading to its phosphorylation at tyrosine residues 239, 240, and 317 within the $\mathrm{CH} 1$ domain (Fig. 1; Rozakis-Adcock et al. 1992, van der Geer et al. 1996, Gotoh et al. 1996). Upon tyrosine phosphorylation, $\mathrm{p} 52^{\mathrm{Shc}}$ recruits Grb2/SOS through a binding event between the SH2 domain of Grb2 and Shc phosphotyrosine residues (Pelicci et al. 1992, Rozakis-Adcock et al. 1992), which ultimately results in the activation of Ras and the MAPK cascade for mitogenesis (Fig. 2; Bonfini et al. 1996). The PTB domain of $\mathrm{p} 52^{\text {Shc }}$ binds to the phosphorylated tyrosine residues of receptor protein tyrosine kinases and functions similar to the $\mathrm{SH} 2$ domain. The $\mathrm{CH} 1$ and $\mathrm{CH} 2$ domains are putative SH3-binding regions (Lotti et al. 1996). Studies have also suggested that $\mathrm{p} 52^{\mathrm{Shc}}$ mediates steroid action on cell proliferation as well as cell survival via tyrosine phosphorylation signal pathway (Kousteni et al. 2001, Lee et al. 2004a). Its aberrant expression and activation may lead to the dysregulation of one of the multipathways in carcinogenesis by steroids, a topic of focus in this review.

$p 66^{\text {shc }}$

p66 $6^{\text {Shc }}$ is also phosphorylated at its tyrosine residues as $\mathrm{p} 52^{\text {Shc }}$ and $\mathrm{p} 46^{\text {Shc }}$ upon growth factor stimulation, e.g., EGF treatment, and forms complexes with Grb2. 


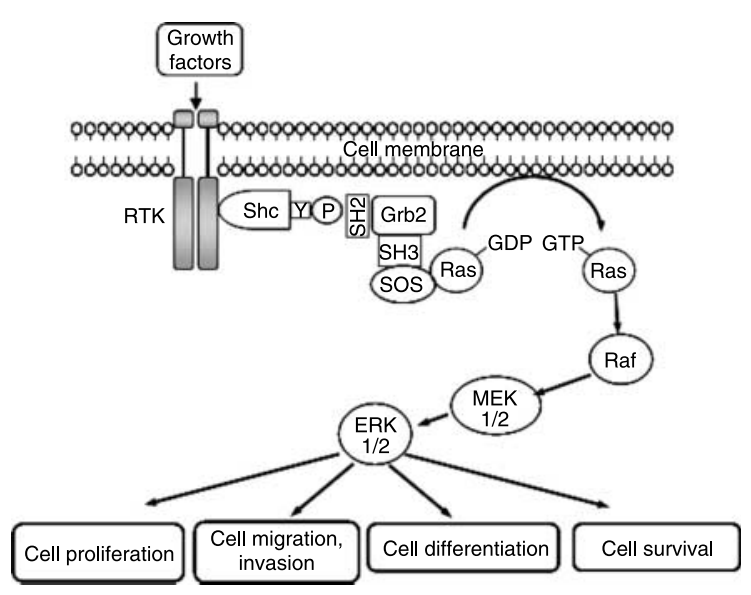

Figure 2 A schematic representation of Shc proteins activating the Ras and MAP kinase cascade. Upon stimulation by growth factors, RTK undergoes dimerization and tyrosine phosphorylation. Subsequently, Shc proteins are recruited and phosphorylated on tyrosine residue via forming a complex with RTK through the $\mathrm{SH} 2$ and/or PTB domain of Shc. The phosphorylated Shc proteins then associate with Grb2 adaptor protein through its tyrosine phosphorylation site to the $\mathrm{SH} 2$ domain of Grb2; the latter is constitutively complexed with SOS through its $\mathrm{SH} 3$ domains. These events result in the translocation of SOS to the plasma membrane and subsequently activate membrane-bound Ras in the exchange of GDP for GTP and trigger the activation of MAP kinase cascade, resulting in cell proliferation, differentiation, migration, invasion, and survival.

However, there are certain functional differences between $\mathrm{p} 66^{\text {Shc }}$ and the other two Shc members. Unlike $\mathrm{p} 52^{\text {Shc }}, \mathrm{p} 66^{\text {Shc }}$ is unable to transform NIH3T3 mouse fibroblasts in culture (Migliaccio et al. 1999) and it could not augment EGF-induced extracellular signal-regulated kinases/mitogen-activated protein kinases (ERK/MAPK) activation in cell cultures such as HeLa, CHO, and COS-1 cells. One possible explanation is that increased expression of $\mathrm{p} 66^{\text {Shc }}$ has resulted in an elevated level of the basal activity of ERK/MAPK in the absence of stimulus, which thus minimizes the extent of further activation by growth factors (Migliaccio et al. 1997, Okada et al. 1997, Veeramani et al. 2005b). Recently, the task of p66 ${ }^{\text {Shc }}$ in mediating stress-induced apoptosis has received much attention (Migliaccio et al. 1999, Orsini et al. 2004, Giorgio et al. 2005). Once p66 ${ }^{\text {Shc }}$ is phosphorylated at Ser-36 in its $\mathrm{CH} 2$ domain in response to various stress factors, such as $\mathrm{H}_{2} \mathrm{O}_{2}$, UV radiation, and chemicals, e.g., Taxol, a fraction of cytosolic p $66^{\mathrm{Shc}}$ associates with heat-shock proteins to mediate apoptotic response (Fig. 3; Orsini et al. 2004) and serves as an apoptotic sensitizer to those signals (Migliaccio et al. 1999). p66 $^{\text {Shc }}$ also acts as a negative regulator of human and mouse $\mathrm{T}$-cell survival and proliferation
(Pacini et al. 2004). In parallel, p66 ${ }^{\text {Shc }}$ knockout mice exhibit a prolonged life span by $30 \%$ and those mouse embryo fibroblast (MEF) cells have increased resistance to oxidative and hypoxic stress (Migliaccio et al. 1999, Trinei et al. 2002, Zaccagnini et al. 2004). Thus, p66 ${ }^{\text {Shc }}$ may function as a longevity gene in mammals. Interestingly, $\mathrm{p} 66^{\mathrm{Shc}}$ expression level in human dermal fibroblasts increases with aging, opposite to the knockout mouse model (Pandolfi et al. 2005). Collectively, these data indicate that $\mathrm{p} 66^{\mathrm{Shc}}$ could function as a sensor and transduce signals in response to cellular stress while more studies are required for its role in human longevity.

Several lines of evidence suggest that aberrant expression of $\mathrm{p} 66^{\text {Shc }}$ could be involved in various stages of carcinogenesis (Jackson et al. 2000, Luzi et al. 2000, Ravichandran 2001, Davol et al. 2003, Lee et al. 2004b, De et al. 2005, Grossman et al. 2007). However, the role and the molecular mechanisms of $\mathrm{p} 66^{\text {Shc }}$ in this mode of regulation remain to be elucidated. In this review, we focus on discussing a novel functional role of $\mathrm{p} 66^{\text {Shc }}$ adaptor protein involved in steroid-related carcinogenesis, leading to its metastasis. This member of Shc protein family may serve as a new target for preventing tumor progression and metastasis.

\section{Role of Shc proteins in steroid-regulated tumor progression and metastasis}

Tumor progression and metastasis are the features of cancer. Cell proliferation, migration, and adhesion to the target tissues are the critical steps that allow tumor cells to obtain the metastatic phenotype. The process of metastasis requires the interaction of malignant cells with at least three distinct microenvironments, including the primary organ, the circulation or lymphatic channels, and the target organ where a metastatic lesion will develop (Radinsky \& Fidler 1992, Mundy

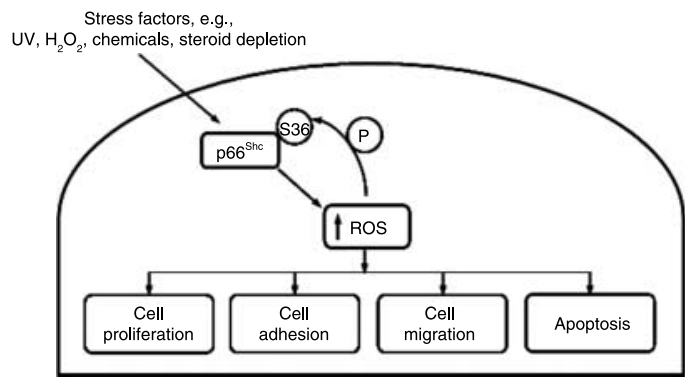

Figure 3 p $66^{\text {Shc }}$ acting as a stress sensor and increasing intracellular ROS level. Increased ROS induces the phosphorylation of serine 36 at $p 66^{\text {Shc }}$ protein that promotes the generation of more ROS, leading to cell proliferation, adhesion, migration, or apoptosis. 
1997, Cooper et al. 2003). Within these microenvironments, several factors are involved in the metastatic cascade (Gopalkrishnan et al. 2001). Tumor cells, after reaching to target organs and tissues, establish as successful foci in the conducible environments. Subsequently, tumor cells proliferate in the new, supportive microenvironment as micrometastasis where they induce angiogenesis for maintaining the growth of new lesion. Induction of angiogenesis is necessary for successful metastasis to meet the nutrient requirements when the tumor size becomes more than $2 \mathrm{~mm}$ in size (Ellis \& Fidler 1996, Gopalkrishnan et al. 2001). Cell proliferation and migration depend on intracellular signals transmitted by the growth factors and adhesion proteins within the extracellular matrix (Pages et al. 1993). Both these processes employ many common intracellular signaling molecules, e.g., Rho family proteins and ERK cascades (Pages et al. 1993, Olson et al. 1995, Anand-Apte et al. 1997, Klemke et al. 1997). It is evident now that Shc isoforms, specifically $\mathrm{p} 52^{\mathrm{Shc}}$ and $\mathrm{p} 66^{\mathrm{Shc}}$, play a crucial role in cell migration and adhesion, in addition to their roles in mediating cell proliferation induced by growth factor receptor signaling (Fig. 4; Klemke et al. 1994, Huttenlocher et al. 1995). These processes involve the rearrangement of actin cytoskeleton, the formation of new integrin substratum contacts, cell contraction, and the release of pre-existing cell-matrix contacts (Lauffenburger \& Horwitz 1996). We will thus discuss the role of $\mathrm{p} 52^{\text {Shc }}$ and $\mathrm{p} 66^{\text {Shc }}$ in these processes and emphasize on steroid regulation.

\section{Role of $\mathrm{p52}^{\mathrm{Shc}}$ in steroid-regulated cell proliferation and migration}

In addition to the classical role in mediating tyrosine kinase-activated pathways, p52 ${ }^{\text {Shc }}$ functions as a primary adaptor protein for mediating the mitogenic signals of steroids at the non-genomic level in human breast and prostate cancer cells (Stevenson et al. 1999, Lee et al. 2004a). In prostate cancer, the data clearly showed that $\mathrm{p} 52^{\mathrm{Shc}}$ is responsible for transducing androgen-activated ErbB-2 signaling, which leads to prostate cancer cell proliferation (Lee et al. 2004a). This androgen-stimulated cell proliferation requires Y317 phosphorylation since p52 ${ }^{\text {Shc }}$ Y317F mutant effectively abolishes androgen stimulation, and that inhibition occurs at certain phases of the cell cycle (Lee et al. 2004a). This observation on the role of $\mathrm{p} 52^{\text {Shc }}$ in androgen action on prostate cancer cells is in parallel to that of $\mathrm{p} 52^{\mathrm{Shc}}$ in estrogen action on breast cancer cells, correlating with ErbB-2 activity (Stevenson \& Frackelton 1998). In addition, vitamin D treatment caused a significant decrease in LNCaP cell growth, which is closely associated with the reduction in ErbB2 activity and its downstream signaling mediator $\mathrm{p} 52^{\text {Shc }}$ via dephosphorylating Y317, thereby emphasizing the involvement of tyrosine phosphorylation of $\mathrm{p} 52^{\mathrm{Shc}}$ in human prostate cancer cell proliferation (Stewart et al. 2005). Furthermore, the p52 ${ }^{\text {Shc }}$ Y317F mutant blocks estrogen-induced cell cycle progression at both the $\mathrm{G}_{0}-\mathrm{G}_{1}$ and $\mathrm{G}_{2}-\mathrm{M}$ junctions (Stevenson et al. 1999). Additionally, in the presence of steroids, ER $\alpha$-transfected HeLa cells exhibit chemoresistance, where $\mathrm{p} 52^{\mathrm{Shc}}$ mediates the anti-apoptotic activity of steroids and thus prevents those cells from etoposideinduced apoptosis (Kousteni et al. 2001). Clearly, $\mathrm{p} 52^{\text {Shc }}$ plays a critical role in mediating steroid action, at least in part, via tyrosine phosphorylation nongenomic signaling.

$\mathrm{p} 52^{\text {Shc }}$ may also be involved in the adhesion process of cancer cells. In rapidly adhering prostate cancer cells, e.g., LNCaP C-81 and PC-3 cells, the phosphorylation level of $\mathrm{p} 52^{\mathrm{Shc}}$ protein at $\mathrm{Y} 317$ correlates with ErbB-2 activation, higher than in slow-adhering LNCaP C-33 cells (Lee et al. 2004a, Yuan et al. 2007). Yet, both the adhesion rate and the Y317 phosphorylation of p52 $^{\text {Shc }}$ as well as ErbB-2 tyrosine phosphorylation level in slow-adhering LNCaP C-33 cells can be up-regulated by steroids. Thus, by correlating tyrosine phosphorylation and adhesion, p52 ${ }^{\text {Shc }}$ may play a crucial role in the adhesion of cancer cells during steroid hormone-induced metastasis. Furthermore, a direct involvement of $\mathrm{p} 52^{\mathrm{Shc}}$ in breast cancer metastasis in transgenic mice that express polyomavirus middle $\mathrm{T}$ antigen with a mutated Shc-binding site has been demonstrated (Webster et al. 1998). Polyomavirus middle $\mathrm{T}$ antigen couples with and activates signaling molecules, such as Src, Shc, and phosphatidylinositol $3^{\prime}$-kinase (PI3K) for its oncogenic capacity. Importantly, in transgenic mice, which have metastatic tumors, the mutated $\mathrm{p} 52^{\mathrm{Shc}}$-binding site on middle $\mathrm{T}$ antigen had reverted to the wild type and regained its function, thus emphasizing the potential importance of the functional $\mathrm{p} 52^{\text {Shc }}$ in the process of metastasis in vivo (Webster et al. 1998). In addition, it has been revealed that in integrin signaling, Shc recruitment to the actin-associated cytoskeleton is important (McGlade et al. 1992, Schlaepfer et al. 1998, Wary et al. 1998). p52 ${ }^{\mathrm{Shc}}$ potentiates integrin signaling, and integrin ligation results in the activation of non-receptor tyrosine kinases, such as Src, Fyn, and focal adhesion kinase (FAK), which phosphorylates $\mathrm{p} 52^{\mathrm{Shc}}$, leading to Ras activation and entering into the cell cycle (McGlade et al. 1992, Mainiero et al. 1995, Wary et al. 1996, 1998). Besides, the SH3 domain of 


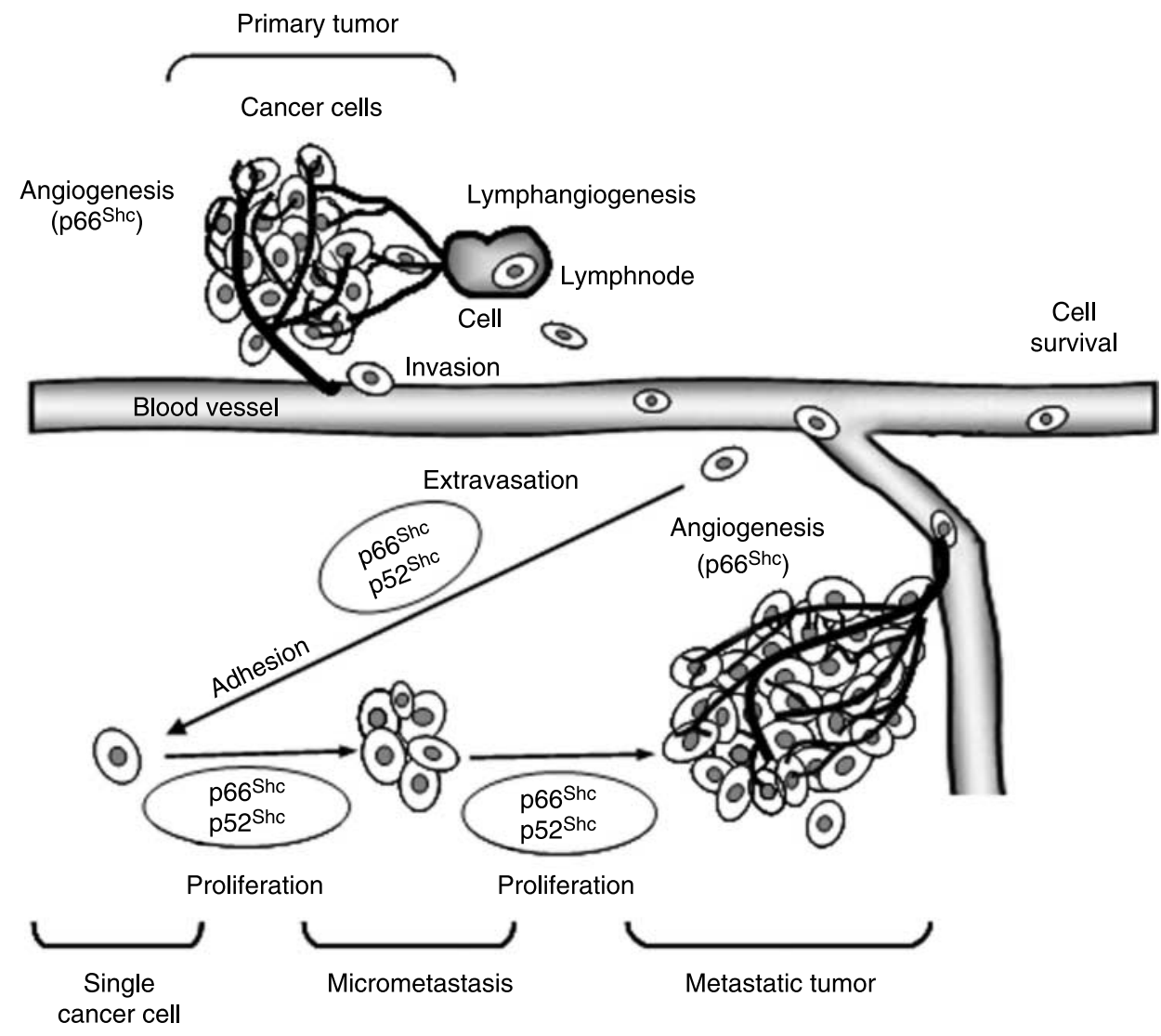

Figure 4 Involvement of $\mathrm{p} 66^{\mathrm{Shc}}$ and $\mathrm{p} 52^{\mathrm{Shc}}$ in tumor metastasis. Growing primary tumors attract new blood vessels, i.e., angiogenesis, and lymphatic vessels, i.e., lymphangiogenesis, to promote local tumor growth, involvement of regional lymph nodes, and finally distant metastasis. In the process of metastasis after degrading or remodeling the basement membrane, metastatic cells detach from the primary tumor mass, intravasate, survive the stress of vascular transportation, and then evade host defense mechanism, which are in part regulated by the adaptor proteins $\mathrm{p} 52^{\mathrm{Shc}}$ and $\mathrm{p} 66^{\mathrm{Shc}}$. Furthermore, targeting via microvessels and cell adhesion molecules, the increased phosphorylation of $p 52^{\mathrm{Shc}}$ and $\mathrm{p} 66^{\mathrm{Shc}}$ proteins mediate the proliferation of tumor cells that metastasize to their preferred sites after extravasation into the target organ parenchyma, and are permitted to reside in the target tissue in which cancer cells respond to transendothelial growth factors from that specific organ. (The figure is adapted from La Porta 2000).

Fyn interacts with the proline-rich region in the $\mathrm{CH} 1$ domain of $\mathrm{p} 52^{\text {Shc }}$ (Thomas \& Bradshaw 1997) and the amino-terminal domain of $\mathrm{p} 52^{\text {Shc }}$ is shown to mediate the association of this adaptor protein to an actin-rich cellular fraction (Thomas \& Bradshaw 1997). Additionally, a mutation of the PTB domain (S154P$\mathrm{p} 52^{\mathrm{Shc}}$ ) abolishes integrin-induced $\mathrm{p} 52^{\mathrm{Shc}}$ tyrosine phosphorylation where the $\mathrm{SH} 2$ domain of $\mathrm{p} 52^{\mathrm{Shc}}$ is dispensable (Collins et al. 1999). p52 ${ }^{\text {Shc }}$ phosphorylation by c-Src can be augmented when the PTB domain binds to phospholipids (Zhou et al. 1995, Sato et al. 1997). These observations explain how the PTB domain localizes $\mathrm{p} 52^{\mathrm{Shc}}$ to the membrane where it becomes phosphorylated by cytoskeleton-associated tyrosine kinases, which finally results in cell migration. It should be noted that these non-receptor tyrosine kinases, e.g., Src, closely interact with steroid hormone signaling pathway (Migliaccio et al. 2000, Guo et al. 2006). The molecular mechanism by which steroids induce cell adhesion and/or migration via $\mathrm{p} 52^{\mathrm{Shc}}$ requires further investigation.

\section{Role of $\mathrm{p} 66^{\mathrm{Shc}}$ in steroid-regulated cell proliferation}

In tyrosine phosphorylation signal transduction pathway, $\mathrm{p} 66^{\text {Shc }}$ conventionally known as an adaptor protein. Interestingly, $\mathrm{p} 66^{\text {Shc }}$ expression closely correlates with the growth rate of prostate cancer cells. For example, $\mathrm{p} 6^{\text {Shc }}$ protein levels in the rapidly growing cells, e.g., PC-3 and DU145, are approximately 4- to 13-fold higher than that in the slowgrowing $\mathrm{LNCaP} \mathrm{C}-33$ cells and are over tenfold higher than that in even slower MDA PCa2b cells (Veeramani et al. 2005b). Recent data indicate that 
p66 ${ }^{\text {Shc }}$ may play a critical role in mediating steroidstimulated cell proliferation. In the presence of steroid hormones (androgen and estrogen), p66 ${ }^{\text {Shc }}$ protein level as well as cell proliferation rate is increased in hormone-sensitive human prostate (LNCaP C-33 and MDA PCa2b), testicular (Tera-1 and Tera-2), and breast (MCF-7) cancer cells, higher than those cells cultured in the absence of steroids (Lee et al. 2004b). Thus, steroids increase $\mathrm{p} 66^{\mathrm{Shc}}$ protein level and concurrently cell growth.

To elucidate directly the functional role of $\mathrm{p} 66^{\text {Shc }}$ protein in steroid-regulated cells, both cDNA and siRNA approaches were employed (Veeramani et al. $2005 b$ ). In both p6 $^{\text {Shc }}$ cDNA, transiently transfected cell population and stable subclones of slow-growing LNCaP C-33 cells, elevated expression of p6 $^{\text {Shc }}$ correlates with increased cell proliferation. On the contrary, a decreased cell growth rate is observed when $066^{\text {Shc }}$ protein is knocked down by its siRNA in the rapidly growing LNCaP C-81 and PC-3 cells. The data clearly establish the causal relationship of $066^{\mathrm{Shc}}$ protein and cell growth. Furthermore, p66 ${ }^{\text {Shc }}$ mediates growth stimulation by androgens (Veeramani et al. 2008). The clinical relevance of these data is supported by the observations that in prostate cancer archival specimens, $\mathrm{p} 66^{\text {Shc }}$ protein level is significantly higher in prostate adenocarcinomatous cells than in adjacent benign glandular cells (Lee et al. $2004 b$ ). Similarly, the expression level of $\mathrm{p} 66^{\text {Shc }}$ is elevated in metastatic breast, ovarian, and thyroid tumors and may serve as a useful prognostic marker for stage-IIA colon cancer (Jackson et al. 2000, Abdollahi et al. 2003, Park et al. 2005, Grossman et al. 2007). Nevertheless, some studies showed that p $66^{\text {Shc }}$ protein is down-regulated in the primary tumors of breast cancers (Davol et al. 2003). Due to the potential importance of $\mathrm{p} 66^{\mathrm{Shc}}$ in carcinogenesis, further studies are needed to clarify the correlation of p66 ${ }^{\text {Shc }}$ expression with breast cancer. In summary, cross-talks between tyrosine phosphorylation signaling and steroid hormones have been well established (Weigel 1996, Meng et al. 2000, Grossmann et al. 2001, Guo et al. 2006, Kraus et al. 2006, Migliaccio et al. 2006, Weigel \& Moore 2007); it is thus reasonable to propose that $\mathrm{p} 66^{\text {Shc }}$ mediates steroid action in steroid-responsive epithelial cells. We therefore hypothesize that the elevated level of p66 ${ }^{\text {Shc }}$ protein in steroid-related cancer cells plays a critical role in up-regulating those cancer cell proliferation and thus contributes to the tumorigenicity of those cancers (Fig. 2). The role of $\mathrm{p} 66^{\text {Shc }}$ in this mode of regulation requires further investigation.

\section{Role of $\mathrm{p} 66^{\mathrm{Shc}}$ in metastasis}

Several studies have shown the involvement of $\mathrm{p} 66^{\text {Shc }}$ in cellular invasion, motility, migration, and/or metastasis. Jackson et al. (2000) have shown that xenograft bone metastasis of breast cancer cell line, MDA-MB-231, expresses $p 66^{\text {Shc }}$ and its metastatic variant F-11 cells have a threefold higher $\mathrm{p} 66^{\mathrm{Shc}}$ expression level. Furthermore, increased expression of p66 $6^{\text {Shc }}$ in lymph node-positive breast cancers correlates with an increased number of positive lymph nodes (Jackson et al. 2000). As higher levels of $\mathrm{p}^{\mathrm{Shc}}$ protein are observed in breast cancer specimens with higher metastatic potential, it suggests the possibility that $\mathrm{p} 66^{\text {Shc }}$ influences cell motility and invasion other than the MAPK pathway (Jackson et al. 2000). Furthermore, Northey et al. (2008) have demonstrated that decrease in the ShcA levels or the expression of a dominant-negative ShcA mutant blocked TGF- $\beta$ induced motility and the invasion of Neu/ErbB-2expressing breast cancer cells, thus exploiting the crucial role of $166^{\mathrm{Shc}}$ in the migration and invasion of cancer cells. In addition, elevated expression of $\mathrm{p} 66^{\mathrm{Shc}}$ by cDNA transfection in LNCaP C-33 cells is associated with increased motility and invasion (Yuan TC, Lin FF \& Lin MF, unpublished data). In parallel, LNCaP C-81 and PC-3 prostate cancer cells express higher levels of $\mathrm{p} 66^{\mathrm{Shc}}$ and exhibit higher metastatic potential than LNCaP C-33 cells in xenograft animals (Veeramani et al. 2005b, Sebeger J $\&$ Lin MF, unpublished observation). The observations on the increased expression of $\mathrm{p} 66^{\mathrm{Shc}}$, but not $\mathrm{p} 52^{\mathrm{Shc}}$ or $\mathrm{p} 46^{\text {Shc }}$, in cell lines with higher metastatic ability and in the node-positive primary breast cancers also imply that $\mathrm{p} 66^{\mathrm{Shc}}$ functions in metastatic pathway.

Integrins play a vital role in cancer progression because of their ability to regulate various intracellular signaling molecules that are essential for cell motility, cell survival, and proliferation (Ruoslahti \& Reed 1994, Hynes et al. 1999). It has been suggested that $\alpha_{\mathrm{v}} \beta_{3}$ integrin plays a critical role in the metastasis of cancer cells to bone marrow (Cooper et al. 2002). $\alpha_{\mathrm{v}} \beta_{3}$ integrin is expressed in breast and lung cancer cells that were originally derived from the bone marrow aspirates. $\alpha_{\mathrm{v}} \beta_{3}$ is also expressed in highly tumorigenic, bone foci-derived human PC-3 prostate cancer cells, but not in low tumorigenic, lymph node foci-derived LNCaP cells (Zheng et al. 1999). The results of recent studies suggest that activated $\alpha_{v} \beta_{3}$ integrin regulates tumor growth in vivo by influencing VEGF expression. The up-regulation of VEGF expression depends on $\alpha_{\mathrm{v}} \beta_{3}$ clustering where it promotes the recruitment of $\mathrm{p} 66^{\mathrm{Shc}}$ and subsequently the phosphorylation of 
$\beta_{3}$-associated $\mathrm{p} 66^{\mathrm{Shc}}$. Phosphorylation of $\mathrm{p} 66^{\mathrm{Shc}}$ is a critical step for $\alpha_{v} \beta_{3}$-mediated potentiation of VEGF expression and tumor vascularization in vivo (De et al. 2005). These findings provide insights into the role of $\alpha_{v} \beta_{3}$ and $\mathrm{p}^{\mathrm{Shc}} 6^{\mathrm{Sh}}$ interaction as a regulator of tumor metastasis and angiogenesis. Thus, down-regulation of p66 ${ }^{\text {Shc }}$ inhibits VEGF expression as well as the tumor growth and angiogenesis in vivo (De et al. 2005). Although the molecular mechanism of $\mathrm{p} 66^{\text {Shc }}$ involvement in metastasis requires further investigations, it is hypothesized that $\mathrm{p} 66^{\mathrm{Shc}}$ is involved in an early step of invasion or during cell motility (Jackson et al. 2000) and plays a role in steroid-regulated metastatic process.

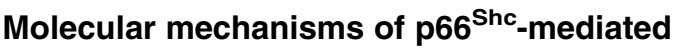 steroid action}

In determining the prostate origin of metastatic cancers, cellular prostatic acid phosphatase (cPAcP) has been used as a biomarker, due to its cell-specific expression (Sakai et al. 1992, Chu \& Lin 1998). The results of several studies collectively indicate that cPAcP exhibit the growth inhibitory activity by functioning as a PTPase (Lin \& Meng 1996, Lin et al. 2001, Veeramani et al. 2005a). In parallel, the expression level of cPAcP negatively correlates with prostatic carcinogenesis, i.e., the level of cPAcP decreases in prostate cancer cells, lower than that in the adjacent non-cancerous cells (Reif et al. 1973, Foti et al. 1977, Loor et al. 1981, Chu \& Lin 1998, Lin et al. 2001). Interestingly, in prostate cancer cells, the level

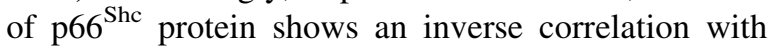
cPAcP expression and has a positive correlation with Erb2 as well as ERK/MAPK activation (Veeramani et al. 2005b). In cPAcP cDNA-transfected stable subclone cells, $\mathrm{p} 66^{\mathrm{Shc}}$ protein level is decreased and ErbB-2 as well as ERK/MAPK activity is diminished, correlating with decreased cell proliferation (Veeramani et al. 2005b). Conversely, elevated p66 ${ }^{\text {Shc }}$ protein level as well as ErbB-2 and ERK/ MAPK activation is observed in cPAcP-inhibited LNCaP C-33 cells by inhibitors (Veeramani et al. 2005b). Similarly, in breast cancer cells, elevated expression of p $6^{\text {Shc }}$ protein correlates with ErbB-2 and/or MAPK1/MAPK activation (Stevenson \& Frackelton 1998, Lee et al. 2004b). In addition, the up-regulation of $\mathrm{p} 66^{\mathrm{Shc}}$ is shown in human ovarian, oral, and lung cancer cells expressing increased levels of ErbB-2 (Xie \& Hung 1996). While the molecular mechanism of this inverse relationship between cPAcP and $\mathrm{p} 66^{\mathrm{Shc}}$ protein remains to investigated further, it should be noted that the inverse correlation of cPAcP with $\mathrm{p} 6^{\text {Shc }}$ as well as ERK/MAPK activation is clinically relevant (Loor et al. 1981, Pontes et al. 1981, Solin et al. 1990, Sakai et al. 1993, Gioeli et al. 1999, Price et al. 1999, Lin et al. 2001, Lee et al. 2004b). Despite the fact that cPAcP may serve as a good prognostic marker for metastatic prostate cancers (Sakai et al. 1993), because of decreased cPAcP level upon tumor progression as well as increased $\mathrm{p} 66^{\text {Shc }}$ protein level in $\mathrm{PCa}$ cells, we contemplate that the p $66^{\mathrm{Shc}} / \mathrm{cPAcP}$ ratio may serve as a competitive surrogate biomarker for predicting the prognosis of advanced prostate carcinoma.

Furthermore, $\mathrm{p} 66^{\text {Shc }}$ may mediate steroid-stimulated cell proliferation via a non-genomic signaling pathway. In the rapidly growing cells, including steroid-stimulated cells, increased oxidative stress by the generation of reactive oxygen species (ROS) might contribute to the elevated $\mathrm{p} 66^{\text {Shc }}$ protein level. p66 $6^{\text {Shc }}$ protein can function as a stress sensor and is involved in regulating the intracellular level of ROS (Trinei et al. 2002). Activated metabolic reactions in the rapidly growing cells lead to increased production of ROS (Klaunig \& Kamendulis 2004), which may in turn increase $\mathrm{p} 66^{\mathrm{Shc}}$ protein levels to mediate oxidative stress signals (Fig. 3). Evidently, upon $\mathrm{H}_{2} \mathrm{O}_{2}$ treatment, in MEF cells or DLD-1 colorectal cancer cells, the expression level of $\mathrm{p} 6^{\mathrm{Shc}}$ protein is increased (Trinei et al. 2002, Pacini et al. 2004). Additionally, ROS-induced phosphorylation of $\mathrm{p} 66^{\text {Shc }}$ protein at Ser-36 residue further promotes the generation of ROS (Nemoto \& Finkel 2002, Orsini et al. 2004). Notably, recent studies reveal that $\mathrm{p} 66^{\text {Shc }}$ protein exhibits endogenous oxidase activity and its amino terminus contains a redox center, which is involved in electron transfer from cytochrome $c$ to molecular oxygen and produces $\mathrm{H}_{2} \mathrm{O}_{2}$. This $\mathrm{H}_{2} \mathrm{O}_{2}$ mediates the opening of transition pores resulting in increased mitochondrial permeability and thus an abnormal high level of $\mathrm{H}_{2} \mathrm{O}_{2}$ can lead to apoptosis (Giorgio et al. 2005). Nevertheless, physiological levels of $\mathrm{H}_{2} \mathrm{O}_{2}$ function as growth stimuli. In addition to the above findings, $\mathrm{p} 66^{\text {Shc }}$ may also increase $\mathrm{H}_{2} \mathrm{O}_{2}$ production through Rac1-SOS-specific pathway (Khanday et al. 2006), possibly leading to androgenindependent cell proliferation (Knight-Krajewski et al. 2004). ROS therefore mediates diverse biological functions, including cell proliferation, cell adhesion, migration, and apoptosis (Fig. 3).

In prostate cancer archival specimens, the ROS level is higher in cancerous cells than in non-cancerous cells, correlating with the proliferation index (Lim et al. 2005). The functional role of ROS as a positive regulator of cell growth, including prostate cancer cells, is apparent in part by inhibiting the PTPase 


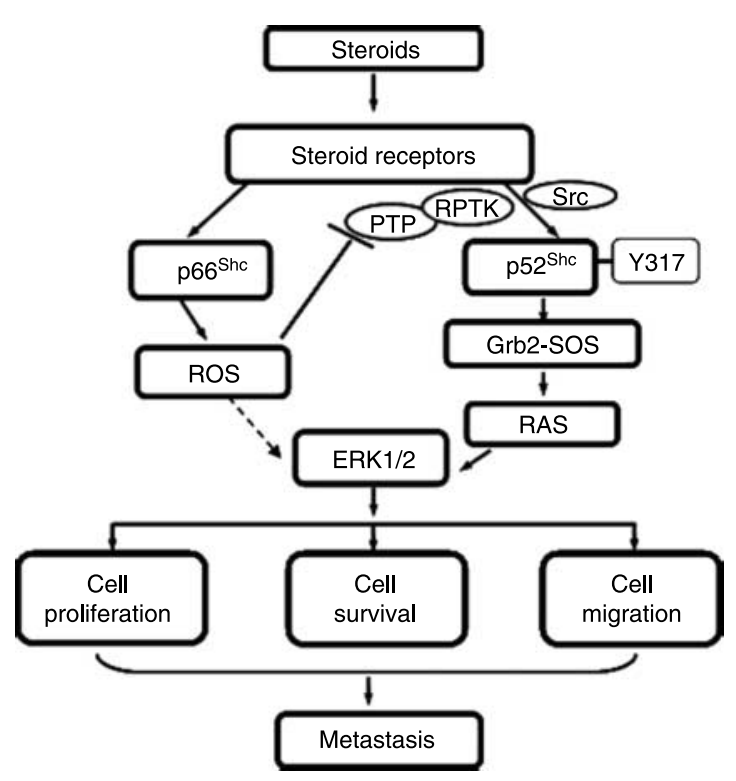

Figure $5 \mathrm{~A}$ proposed scheme of steroid-regulated cancer progression via Shc proteins. Upon steroid activation, p52 $2^{\text {Shc }}$ undergoes phosphorylation at Y317 and promotes tumor growth at least in part via transducing signals through the Grb2-Ras-MAPK pathway. Like $\mathrm{p} 52^{\text {Shc }}, \mathrm{p} 66^{\text {Shc }}$ protein also promotes tumor progression, nevertheless, via mediating oxidative stress signals through the generation of ROS. Upon stimulation by steroids, $\mathrm{p} 66^{\mathrm{Shc}}$ is translocated to mitochondria via Ser-36 phosphorylation-independent manner resulting in the generation of ROS. ROS may then inhibit PTP, resulting in RPTK activation, ERK/MAPK activation, and promote cell proliferation, survival, and migration, which collectively lead to metastasis.

activity, and thus the corresponding RPTK can be activated (Finkel \& Holbrook 2000, Liu et al. 2002, Lou et al. 2008, Veeramani et al. 2008). Furthermore, steroid hormones, e.g., androgens and estrogens, and growth factors, such as EGF, can up-regulate ROS production in cells, as such; cell proliferation is promoted (Sundaresan et al. 1996, Liu et al. 2002). This is consistent with our findings that androgenic treatment of LNCaP C-33 cells promotes cell proliferation via decreasing cellular PAcP and increasing p66 ${ }^{\text {Shc }}$ protein level and ROS production as well as ErbB-2 tyrosine phosphorylation (Meng et al. 2000, Veeramani et al. 2008). Therefore, an inverse correlation of $\mathrm{p}^{\mathrm{Shc}}$ and $\mathrm{cPAcP}$ in prostate cancer cell is observed. Additionally, it has been demonstrated that ROS may play a critical role in the initiation and/or early progression of prostate cancer; as such, antioxidants are used in clinical trials for this cancer prevention (Veeramani \& Lin 2007). Collectively, the data indicate that $\mathrm{p} 66^{\text {Shc }}$ can mediate non-genomic steroid action on cell proliferation and carcinogenesis including metastasis, while the molecular mechanisms require further investigations.

\section{Conclusion and perspective}

To discover the novel therapeutic targets for the prevention of tumor progression and metastasis, identifying the functional molecules that are involved in enhancing or suppressing these processes is one of the major challenges. The metastatic process in carcinogenesis is regulated dynamically by numerous factors, including growth factors, hormones, and extracellular matrices. To establish a metastatic lesion, tumor cells must complete all the steps in metastatic processes. Several studies have already shown that Shc proteins, including $\mathrm{p} 52^{\mathrm{Shc}}$ and $\mathrm{p} 66^{\mathrm{Shc}}$, have marked effects on cell proliferation, invasion, and migration. In this review, we discuss a novel role of $\mathrm{p} 52^{\text {Shc }}$ and p66 $6^{\text {Shc }}$ in mediating steroid action on tumor proliferation and metastasis. We further present a novel nongenomic mechanism by which steroid signaling via $\mathrm{p} 52^{\mathrm{Shc}}$ and $\mathrm{p} 66^{\mathrm{Shc}}$ induces cancer cell proliferation, survival, migration and ultimately metastasis (Fig. 5). Nevertheless, the role of other key players engaged with $\mathrm{p} 52^{\text {Shc }}$ and/or $\mathrm{p} 66^{\text {Shc }}$ signaling pathway has yet to be identified. Thus, the molecular mechanisms by which $\mathrm{p} 52^{\text {Shc }}$ and $\mathrm{p} 66^{\text {Shc }}$ mediate steroid hormoneinduced carcinogenesis require further investigations. Understanding the role of Shc adaptor proteins in cancer biology including the determination of the upstream regulators and downstream effectors of Shc functional pathways may lead to the development of novel anti-tumor strategies for targeting against steroid-induced epithelial cancers.

\section{Declaration of interest}

All authors declare that there is no conflict of interest that could be perceived as prejudicing the impartiality of the research reported.

\section{Funding}

This study was supported in part by the National Cancer Institute, National Institutes of Health (R01 CA88184), Department of Defense (W81XWH-06-1-0070 and W81XWH-08-1-0459), Nebraska Research Initiative for Cancer Glycobiology, and Nebraska Cancer and Smoking Disease Research Program LB 506 (2008-20).

\section{Acknowledgements}

We thank Ms Fen-Fen Lin for her tremendous help in our studies on Shc proteins. 


\section{References}

Abdollahi A, Gruver BN, Patriotis C \& Hamilton TC 2003 Identification of epidermal growth factor-responsive genes in normal rat ovarian surface epithelial cells. Biochemical and Biophysical Research Communications 18 188-197.

Alzamora R \& Harvey BJ 2008 Direct binding and activation of protein kinase $\mathrm{C}$ isoforms by steroid hormones. Steroids 73 885-888.

Anand-Apte B, Zetter BR, Viswanathan A, Qiu RG, Chen J, Ruggieri R \& Symons M 1997 Platelet-derived growth factor and fibronectin-stimulated migration are differentially regulated by the Rac and extracellular signalregulated kinase pathways. Journal of Biological Chemistry 272 30688-30692.

Armen TA \& Gay CV 2000 Simultaneous detection and functional response of testosterone and estradiol receptors in osteoblast plasma membranes. Journal of Cellular Biochemistry 79 620-627.

Benten WP, Lieberherr M, Giese G \& Wunderlich F 1998 Estradiol binding to cell surface raises cytosolic free calcium in T cells. FEBS Letters 422 349-353.

Benten WP, Lieberherr M, Giese G, Wrehlke C, Stamm O, Sekeris CE, Mossmann H \& Wunderlich F 1999a Functional testosterone receptors in plasma membranes of T cells. FEBS Journal 13 123-133.

Benten WP, Lieberherr M, Stamm O, Wrehlke C, Guo Z \& Wunderlich F $1999 b$ Testosterone signaling through internalizable surface receptors in androgen receptorfree macrophages. Molecular Biology of the Cell 10 3113-3123.

Berridge MJ, Bootman MD \& Lipp P 1998 Calcium - a life and death signal. Nature 395 645-648.

Van Bömmel T, Marsen T \& Bojar H 1987 Effects of highdose medroxyprogesterone acetate and various other steroid hormones on plasma membrane lipid mobility in CAMA-1 mammary cancer cells. Anticancer Research 7 1217-1223.

Bonfini L, Migliaccio E, Pelicci G, Lanfrancone L \& Pelicci PG 1996 Not all Shc's roads lead to Ras. Trends in Biochemical Sciences 21 257-261.

Choudhury GG, Karamitsos C, Hernandez J, Gentilini A, Bardgette J \& Abboud HE 1997 PI-3-kinase and MAPK regulate mesangial cell proliferation and migration in response to PDGF. American Journal of Physiology 273 F931-F938.

Chu TM \& Lin MF 1998 PSA and acid phosphatase in the diagnosis of prostate cancer. Journal of Clinical Ligand Assay 21 24-34.

Collins LR, Ricketts WA, Yeh L \& Cheresh D 1999 Bifurcation of cell migratory and proliferative signaling by the adaptor protein Shc. Journal of Cell Biology 147 1561-1568.

Cooper CR, Chay CH \& Pienta KJ 2002 The role of alpha(v)beta(3) in prostate cancer progression. Neoplasia 4 191-194.
Cooper CR, Chay CH, Gendernalik JD, Lee H-L, Bhatia J, Taichman RS, McCauley LK, Keller ET \& Pienta KJ 2003 Stromal factors involved in prostate carcinoma metastasis to bone. Cancer 97 739-747.

Dabrosin C, Ollinger K, Ungerstedt U \& Hammar M 1997 Variability of glutathione levels in normal breast tissue and subcutaneous fat during the menstrual cycle: an in vivo study with microdialysis technique.

Journal of Clinical Endocrinology and Metabolism 82 1382-1384.

Davol PA, Bagdasaryan R, Elfenbein GJ, Maizel AL \& Frackelton AR Jr 2003 Shc proteins are strong, independent prognostic markers for both node negative and node positive primary breast cancer. Cancer Research 63 6772-6783.

De S, Razorenova O, McCabe NP, O'Toole T, Qin J \& Byzova TV 2005 VEGF-integrin interplay controls tumor growth and vascularization. PNAS 102 7589-7594.

Devanesan P, Santen RJ, Bocchinfuso WP, Korach KS, Rogan EG \& Cavalieri E 2001 Catechol estrogen metabolites and conjugates in mammary tumors and hyperplastic tissue from estrogen receptor-alpha knockout (ERKO)/Wnt-1 mice: implications for initiation of mammary tumors. Carcinogenesis 22 1573-1576.

Dickson RB \& Lippman ME 1987 Estrogenic regulation of growth and polypeptide growth factor secretion in human breast carcinoma. Endocrine Reviews 8 29-43.

Duval D, Durant S \& Homo-Delarche F 1983 Non-genomic effects of steroids. Interactions of steroid molecules with membrane structures and functions. Biochimica et Biophysica Acta 737 409-442.

Ellis LM \& Fidler IJ 1996 Angiogenesis and metastasis. European Journal of Cancer 32A 2451-2460.

Engebraaten O, Bjerkvig R, Pedersen PH \& Laerum OD 1993 Effects of EGF, bFGF, NGF, and PDGF (bb) on cell proliferative, migratory, and invasive capacities of human brain-tumour biopsies in vitro. International Journal of Cancer 53 209-214.

Er F, Michels G, Gassanov N, Rivero F \& Hoppe UC 2004 Testosterone induces cytoprotection by activating ATPsensitive $\mathrm{K}^{+}$channels in the cardiac mitochondrial inner membrane. Circulation 110 3100-3107.

Er F, Michels G, Brandt MC, Khan I, Haase H, Eicks M, Lindner M \& Hoppe UC 2007 Impact of testosterone on cardiac L-type calcium channels and $\mathrm{Ca}^{2+}$ sparks: acute actions antagonize chronic effects. Cell Calcium $\mathbf{4 1}$ 467-477.

Estrada M, Espinosa A, Muller M \& Jaimovich E 2003 Testosterone stimulates intracellular calcium release and mitogen-activated protein kinases via a $\mathrm{G}$ protein-coupled receptor in skeletal muscle cells. Endocrinology 144 3586-3597.

Finkel T \& Holbrook NJ 2000 Oxidants, oxidative stress and the biology of ageing. Nature 9 239-247.

Fortunati N 1999 Sex hormone-binding globulin: not only a transport protein. What news is around the corner? Journal of Endocrinological Investigation 22 223-234. 
Fortunati N, Fissore F, Fazzari A, Becchis M, Comba A, Catalano MG, Berta L \& Frairia R 1996 Sex steroid binding protein exerts a negative control on estradiol action in MCF-7 cells (human breast cancer) through cyclic adenosine 30,50-monophosphate and protein kinase A. Endocrinology 137 686-692.

Foti AG, Cooper JF, Herschman H \& Malvaez RR 1977 Detection of prostatic cancer by solid-phase radioimmunoassay of serum prostatic acid phosphatase. New England Journal of Medicine 297 1357-1361.

van der Geer P, Wiley S, Gish GD \& Pawson T 1996 The Shc adaptor protein is highly phosphorylated at conserved, twin tyrosine residues (Y239/240) that mediate proteinprotein interactions. Current Biology 6 1435-1444.

Gioeli D, Mandell JW, Petroni GR, Frierson HF Jr \& Weber MJ 1999 Activation of mitogen-activated protein kinase associated with prostate cancer progression. Cancer Research 59 279-284.

Giorgio M, Migliaccio E, Orsini F, Paolucci D, Moroni M, Contursi C, Pelliccia G, Luzi L, Minucci S, Marcaccio M et al. 2005 Electron transfer between cytochrome $\mathrm{c}$ and p66Shc generates reactive oxygen species that trigger mitochondrial apoptosis. Cell 122 221-233.

Gopalkrishnan RV, Kang DC \& Fisher PB 2001 Molecular markers and determinants of prostate cancer metastasis. Journal of Cellular Physiology 189 245-256.

Gotoh N, Tojo A \& Shibuya M 1996 A novel pathway from phosphorylation of tyrosine residues 239/240 of Shc, contributing to suppress apoptosis by IL-3. EMBO Journal 15 6197-6204.

Grossman SR, Lyle S, Resnick MB, Sabo E, Lis RT, Rosinha E, Liu Q, Hsieh CC, Bhat G, Frackelton AR Jr et al. 2007 p66 Shc tumor levels show a strong prognostic correlation with disease outcome in stage IIA colon cancer. Clinical Cancer Research 13 5798-5804.

Grossmann ME, Huang H \& Tindall DJ 2001 Androgen receptor signaling in androgen-refractory prostate cancer. Journal of the National Cancer Institute 93 1687-1697.

Guo Z, Dai B, Jiang T, Xu K, Xie Y, Kim O, Nesheiwat I, Kong X, Melamed J, Handratta VD et al. 2006 Regulation of androgen receptor activity by tyrosine Phosphorylation. Cancer Cell 10 309-319.

Hamada J, Nagayasu H, Takayama M, Kawano T, Hosokawa M \& Takeichi N 1995 Enhanced effect of epidermal growth factor on pulmonary metastasis and in vitro invasion of rat mammary carcinoma cells. Cancer Letters 89 $161-167$.

Hammes SR \& Levin ER 2007 Extranuclear steroid receptors: nature and actions. Endocrine Reviews $\mathbf{2 8}$ 726-741.

Harvey BJ, Doolan CM, Condliffe SB, Renard C, Alzamora R \& Urbach V 2002 Non-genomic convergent and divergent signalling of rapid responses to aldosterone and estradiol in mammalian colon. Steroids 67 483-491.

Henderson BE \& Feigelson HS 2000 Hormonal carcinogenesis. Carcinogenesis 21 427-433.
Huttenlocher A, Sandborg RR \& Horwitz AF 1995 Adhesion in cell migration. Current Opinion in Cell Biology 7 697-706.

Hynes RO, Bader BL \& Hodivala-Dilke K 1999 Integrins in vascular development. Brazilian Journal of Medical and Biological Research 32 501-510.

Jackson JG, Yoneda T, Clark GM \& Yee D 2000 Elevated levels of p66 shc are found in breast cancer cell lines and primary tumors with high metastatic potential. Clinical Cancer Research 6 1135-1139.

Jakacka M, Ito M, Weiss J, Chien PY, Gehm BD \& Jameson JL 2001 Estrogen receptor binding to DNA is not required for its activity through the nonclassical AP1 pathway. Journal of Biological Chemistry 276 13615-13621.

Kampa M, Papakonstanti EA, Hatzoglou A, Stathopoulos EN, Stournaras C \& Castanas E 2002 The human prostate cancer cell line $\mathrm{LNCaP}$ bears functional membrane testosterone receptors that increase PSA secretion and modify actin cytoskeleton. FEBS Journal 16 1429-1431.

Kelly MJ, Lagrange AH, Wagner EJ \& Rønnekleiv OK 1999 Rapid effects of estrogen to modulate $G$ protein-coupled receptors via activation of protein kinase A and protein kinase C pathways. Steroids 64 64-75.

Khanday FA, Santhanam L, Kasuno K, Yamamori T, Naqvi A, Dericco J, Bugayenko A, Mattagajasingh I, Disanza A, Scita G et al. 2006 Sos-mediated activation of rac1 by p66shc. Journal of Cell Biology 172 817-822.

Kim HP, Lee JY, Jeong JK, Bae SW, Lee HK \& Jo I 1999 Nongenomic stimulation of nitric oxide release by estrogen is mediated by estrogen receptor alpha localized in caveolae. Biochemical and Biophysical Research Communications 263 257-262.

Klaunig JE \& Kamendulis LM 2004 The role of oxidative stress in carcinogenesis. Annual Review of Pharmacology and Toxicology 44 239-267.

Klemke RL, Yebra M, Bayna EM \& Cheresh DA 1994 Receptor tyrosine kinase signaling required for integrin alpha v beta 5-directed cell motility but not adhesion on vitronectin. Journal of Cell Biology 127 859-866.

Klemke RL, Cai S, Giannini AL, Gallagher PJ, de Lanerolle P \& Cheresh DA 1997 Regulation of cell motility by mitogen-activated protein kinase. Journal of Cell Biology 137 481-492.

Knight-Krajewski S, Welsh CF, Liu Y, Lyons LS, Faysal JM, Yang ES \& Burnstein KL 2004 Deregulation of the Rho GTPase, Rac1, suppresses cyclin-dependent kinase inhibitor p21(CIP1) levels in androgen-independent human prostate cancer cells. Oncogene 23 5513-5522.

Kousteni S, Bellido T, Plotkin LI, O’Brien CA, Bodenner DL, Han L, Han K, DiGregorio GB, Katzenellenbogen JA, Katzenellenbogen BS et al. 2001 Nongenotropic, sexnonspecific signaling through the estrogen or androgen receptors: dissociation from transcriptional activity. Cell 104 719-730. 
Kraus S, Gioeli D, Vomastek T, Gordon V \& Weber MJ 2006 Receptor for activated C kinase 1 (RACK1) and Src regulate the tyrosine phosphorylation and function of the androgen receptor. Cancer Research 66 11047-11054.

Lauffenburger DA \& Horwitz AF 1996 Cell migration: a physically integrated molecular process. Cell 84 359-369.

Lee MS, Igawa T \& Lin MF $2004 a$ Tyrosine-317 of p52(Shc) mediates androgen-stimulated proliferation signals in human prostate cancer cells. Oncogene 23 3048-3058.

Lee MS, Igawa T, Chen SJ, Van Bemmel D, Lin JS, Lin FF, Johansson SL, Christman JK \& Lin MF $2004 b$ p66Shc protein is upregulated by steroid hormones in hormonesensitive cancer cells and in primary prostate carcinomas. International Journal of Cancer 108 672-678.

Levin ER 2005 Integration of the extranuclear and nuclear actions of estrogen. Molecular Endocrinology 19 1951-1959.

Lieberherr M \& Grosse B 1994 Androgens increase intracellular calcium concentration and inositol 1,4,5trisphosphate and diacylglycerol formation via a pertussis toxin-sensitive G-protein. Journal of Biological Chemistry 269 7217-7223.

Lim SD, Sun C, Lambeth JD, Marshall F, Amin M, Chung L, Petros JA \& Arnold RS 2005 Increased Nox1 and hydrogen peroxide in prostate cancer. Prostate 62 200-207.

Lin MF \& Meng TC 1996 Tyrosine phosphorylation of a $185 \mathrm{kDa}$ phosphoprotein (pp185) inversely correlates with the cellular activity of human prostatic acid phosphatase. Biochemical and Biophysical Research Communications 226 206-213.

Lin MF, Lee MS, Zhou XW, Andressen JC, Meng TC, Johansson SL, West WW, Taylor RJ, Anderson JR \& Lin FF 2001 Decreased expression of cellular prostatic acid phosphatase increases tumorigenicity of human prostate cancer cells. Journal of Urology 166 1943-1950.

Liu SL, Lin X, Shi DY, Cheng J, Wu CQ \& Zhang YD 2002 Reactive oxygen species stimulated human hepatoma cell proliferation via cross-talk between PI3-K/PKB and JNK signaling pathways. Archives of Biochemistry and Biophysics 406 173-182.

Loor R, Wang MC, Valenzuela L \& Chu TM 1981 Expression of prostatic acid phosphatase in human prostate cancer. Cancer Letters 14 63-69.

Lotti LV, Lanfrancone L, Migliaccio E, Zompetta C, Pelicci G, Salcini AE, Falini B, Pelicci PG \& Torrisi MR 1996 Shc proteins are localized on endoplasmic reticulum membranes and are redistributed after tyrosine kinase receptor activation. Molecular and Cellular Biology 16 1946-1954.

Lou YW, Chen YY, Hsu SF, Chen RK, Lee CL, Khoo KH, Tonks NK \& Meng TC 2008 Redox regulation of the protein tyrosine phosphatase PTP1B in cancer cells. FEBS Journal 275 69-88.

Lu ML, Schneider MC, Zheng Y, Zhang X \& Richie JP 2001 Caveolin-1 interacts with androgen receptor. A positive modulator of androgen receptor mediated transactivation. Journal of Biological Chemistry 276 13442-13451.
Lu Q, Pallas DC, Surks HK, Baur WE, Mendelsohn ME \& Karas RH 2004 Striatin assembles a membrane signaling complex necessary for rapid, nongenomic activation of endothelial NO synthase by estrogen receptor alpha. PNAS 101 17126-17131.

Luttrell LM, Hawes BE, van Biesen T, Luttrell DK, Lansing TJ \& Lefkowitz RJ 1996 Role of c-Src tyrosine kinase in G protein-coupled receptor- and Gbetagamma subunitmediated activation of mitogen-activated protein kinases. Journal of Biological Chemistry 271 19443-19450.

Luzi L, Confalonieri S, Di Fiore PP \& Pelicci PG 2000 Evolution of Shc functions from nematode to human. Current Opinion in Genetics \& Development 10 668-674.

Mainiero F, Pepe A, Wary KK, Spinardi L, Mohammadi M, Schlessinger J \& Giancotti FG 1995 Signal transduction by the alpha 6 beta 4 integrin: distinct beta 4 subunit sites mediate recruitment of Shc/Grb2 and association with the cytoskeleton of hemidesmosomes. EMBO Journal 144 470-481.

McGlade J, Cheng A, Pelicci G, Pelicci PG \& Pawson T 1992 Shc proteins are phosphorylated and regulated by the v-Src and v-Fps protein-tyrosine kinases. PNAS 89 8869-8873.

Meng TC, Lee MS \& Lin MF 2000 Interaction between protein tyrosine phosphatase and protein tyrosine kinase is involved in androgen-promoted growth of human prostate cancer cells. Oncogene 19 2664-2677.

Meyer G \& Feldman EL 2002 Signaling mechanisms that regulate actin-based motility processes in the nervous system. Journal of Neurochemistry 83 490-503.

Michels G, Er F, Eicks M, Herzig S \& Hoppe UC 2006 Longterm and immediate effect of testosterone on single T-type calcium channel in neonatal rat cardiomyocytes. Endocrinology 147 5160-5169.

Migliaccio E, Mele S, Salcini AE, Pelicci G, Lai KM, Superti-Furga G, Pawson T, Di Fiore PP, Lanfrancone L \& Pelicci PG 1997 Opposite effects of the p52Shc/p46Shc and p66Shc splicing isoforms on the EGF receptor-MAP kinase-fos signaling pathway. EMBO Journal 16 706-716.

Migliaccio E, Giorgio M, Mele S, Pelicci G, Reboldi P, Pandolfi PP, Lanfrancone L \& Pelicci PG 1999 The p66shc adaptor protein controls oxidative stress response and life span in mammals. Nature $\mathbf{4 0 2}$ 309-313.

Migliaccio A, Castoria G, Di Domenico M, de Falco A, Bilancio A, Lombardi M, Barone MV, Ametrano D, Zannini MS, Abbondanza C et al. 2000 Steroid-induced androgen receptor-oestradiol receptor beta-Src complex triggers prostate cancer cell proliferation. EMBO Journal 19 5406-5417.

Migliaccio A, Castoria G, Di Domenico M, Ciociola A, Lombardi M, De Falco A, Nanayakkara M, Bottero D, De Stasio R, Varricchio L et al. 2006 Crosstalk between EGFR and extranuclear steroid receptors. Annals of the New York Academy of Sciences 1089 194-200. 
Mignatti P, Morimoto T \& Rifkin DB 1991 Basic fibroblast growth factor released by single, isolated cells stimulates their migration in an autocrine manner. PNAS $\mathbf{8 8}$ 11007-11011.

Mundy GR 1997 Mechanisms of bone metastasis. Cancer $\mathbf{8 0}$ 1546-1556.

Nakhla AM, Romas NA \& Rosner W 1997 Estradiol activates the prostate androgen receptor and prostatespecific antigen secretion through the intermediacy of sex hormone-binding globulin. Journal of Biological Chemistry 272 6838-6841.

Nemoto S \& Finkel T 2002 Redox regulation of forkhead proteins through a p66shc-dependent signaling pathway. Science 29 2450-2452.

Nemoto S, Combs CA, French S, Ahn BH, Fergusson MM, Balaban RS \& Finkel T 2006 The mammalian longevity-associated gene product p66shc regulates mitochondrial metabolism. Journal of Biological Chemistry 281 10555-10560.

Northey JJ, Chmielecki J, Ngan E, Russo C, Annis MG, Muller WJ \& Siegel PM 2008 Signaling through ShcA is required for transforming growth factor beta- and Neu/ErbB-2-induced breast cancer cell motility and invasion. Molecular and Cellular Biology 28 3162-3176.

Okada S, Kao AW, Ceresa BP, Blaikie P, Margolis B \& Pessin JE 1997 The 66-kDa Shc isoform is a negative regulator of the epidermal growth factor-stimulated mitogen-activated protein kinase pathway. Journal of Biological Chemistry 272 28042-28049.

Okamoto T, Schlegel A, Scherer PE \& Lisanti MP 1998 Caveolins, a family of scaffolding proteins for organizing 'preassembled signaling complexes' at the plasma membrane. Journal of Biological Chemistry 273 5419-5422.

Olson MF, Ashworth A \& Hall A 1995 An essential role for Rho, Rac, and Cdc42 GTPases in cell cycle progression through G1. Science 269 1270-1272.

Orsini F, Migliaccio E, Moroni M, Contursi C, Raker VA, Piccini D, Martin-Padura I, Pelliccia G, Trinei M, Bono M et al. 2004 The life span determinant p66shc localizes to mitochondria where it associates with mitochondrial heat shock protein 70 and regulates trans-membrane potential. Journal of Biological Chemistry 279 25689-25695.

Pacini S, Pellegrini M, Migliaccio E, Patrussi L, Ulivieri C, Ventura A, Carraro F, Naldini A, Lanfrancone L, Pelicci P et al. 2004 p66SHC promotes apoptosis and antagonizes mitogenic signaling in T cells. Molecular and Cellular Biology 24 1747-1757.

Pages G, Lenormand P, L'Allemain G, Chambard JC, Meloche S \& Pouyssegur J 1993 Mitogen-activated protein kinases $\mathrm{p} 42 \mathrm{mapk}$ and $\mathrm{p} 44 \mathrm{mapk}$ are required for fibroblast proliferation. PNAS 90 8319-8323.

Pandolfi S, Bonafe M, Di Tella L, Tiberi L, Salvioli S, Monti D \& Sorbi S 2005 Franceschi Cp66Shc is highly expressed in fibroblasts from centenarians. Mechanisms of Ageing and Development 126 839-844.
Park YJ, Kim TY, Lee SH, Kim H, Kim SW, Shong M, Yoon YK, Cho BY \& Park DJ 2005 p66shc expression in proliferating thyroid cells is regulated by thyrotropin receptor signaling. Endocrinology 146 2473-2480.

Pawson T \& Scott JD 1997 Signaling through scaffold, anchoring, and adaptor proteins. Science 278 2075-2080.

Pelicci G, Lanfrancone L, Grignani F, McGlade J, Cavallo F, Forni G, Nicoletti I, Pawson T \& Pelicci PG 1992 A novel transforming protein (SHC) with an $\mathrm{SH} 2$ domain is implicated in mitogenic signal transduction. Cell $\mathbf{7 0}$ 93-104.

Pelicci G, Giordano S, Zhen Z, Salcini AE, Lanfrancone L, Bardelli A, Panayotou G, Waterfield MD, Ponzetto C, Pelicci PG et al. 1995 The motogenic and mitogenic responses to HGF are amplified by the Shc adaptor protein. Oncogene 10 1631-1638.

Pierce KL, Premont RT \& Lefkowitz RJ 2002 Seventransmembrane receptors. Nature Reviews. Molecular Cell Biology 3 639-650.

Pontes JE, Rose NR, Ercole C \& Pierce JM Jr 1981 Immunofluorescence for prostatic acid phosphatase: clinical applications. Journal of Urology 126 187-189.

La Porta CA 2000 Links nPKCdelta a new therapeutic marker for melanoma metastasis? International Journal of Molecular Medicine 5 467-471.

Price DT, Della Rocca G, Guo C, Ballo MS, Schwinn DA \& Luttrell LM 1999 Activation of extracellular signal regulated kinase in human prostate cancer. Journal of Urology 162 1537-1542.

Radinsky R \& Fidler IJ 1992 Regulation of tumor cell growth at organ-specific metastases. In Vivo 6 325-331.

Ratner S, Patrick P \& Bora G 1992 Lymphocyte development of adherence and motility in extracellular matrix during IL-2 stimulation. Journal of Immunology 149 681-688.

Ravichandran KS 2001 Signaling via Shc family adapter proteins. Oncogene 20 6322-6330.

Ray P, Ghosh SK, Zhang DH \& Ray A 1997 Repression of interleukin- 6 gene expression by 17 beta-estradiol: inhibition of the DNA-binding activity of the transcription factors NF-IL6 and NF-kappa B by the estrogen receptor. FEBS Letters 409 79-85.

Reif AE, Schlesinger RM, Fish CA \& Robinson CM 1973 Acid phosphatase isozymes in cancer of the prostate. Cancer 31 689-699.

Ripple MO, Henry WF, Rago RP \& Wilding G 1997 Prooxidant-antioxidant shift induced by androgen treatment of human prostate carcinoma cells. Journal of the National Cancer Institute 89 40-48.

Ripple MO, Henry WF, Schwarze SR, Wilding G \& Weindruch R 1999 Effect of antioxidants on androgeninduced AP-1 and NF-kappaB DNA-binding activity in prostate carcinoma cells. Journal of the National Cancer Institute 91 1227-1232.

Rosner W, Hryb DJ, Khan MS, Nakhla AM \& Romas NA 1999 Androgen and estrogen signaling at the cell membrane via G-proteins and cyclic adenosine monophosphate. Steroids 64 100-106. 
Rozakis-Adcock M, McGlade J, Mbamalu G, Pelicci G, Daly R, Li W, Batzer A, Thomas S, Brugge J, Pelicci PG et al. 1992 Association of the Shc and Grb2/Sem5 SH2containing proteins is implicated in activation of the Ras pathway by tyrosine kinases. Nature $\mathbf{3 6 0}$ 689-692.

Ruoslahti E \& Reed JC 1994 Anchorage dependence, integrins, and apoptosis. Cell 77 477-478.

Sachs M, Weidner KM, Brinkmann V, Walther I, Obermeier A, Ullrich A \& Birchmeier W 1996 Motogenic and morphogenic activity of epithelial receptor tyrosine kinases. Journal of Cell Biology 133 1095-1107.

Safe S 2001 Transcriptional activation of genes by 17 betaestradiol through estrogen receptor-Sp1 interactions Vitamins. Hormones 62 231-252.

Sakai H, Igawa T, Saha PK, Nomata K, Yushita Y, Kanetake H \& Saito Y 1992 A case of prostatic carcinoma presenting as a metastatic orbital tumor. Hinyokika Kiyo. Acta Urologica Japonica 38 77-80.

Sakai H, Yogi Y, Minami Y, Yushita Y, Kanetake H \& Saito Y 1993 Prostate specific antigen and prostatic acid phosphatase immunoreactivity as prognostic indicators of advanced prostatic carcinoma. Journal of Urology 149 1020-1023.

Sato K, Gotoh N, Otsuki T, Kakumoto M, Aoto M, Tokmakov AA, Shibuya M \& Fukami Y 1997 Tyrosine residues 239 and 240 of Shc are phosphatidylinositol 4,5bisphosphate-dependent phosphorylation sites by c-Src.

Biochemical and Biophysical Research Communications 240 399-404.

Schlaepfer DD, Jones KC \& Hunter T 1998 Multiple Grb2mediated integrin-stimulated signaling pathways to ERK2/mitogen-activated protein kinase: summation of both c-Src- and focal adhesion kinase-initiated tyrosine phosphorylation events. Molecular and Cellular Biology 18 2571-2585.

Solin T, Kontturi M, Pohlmann R \& Vihko P 1990 Gene expression and prostate specificity of human prostatic acid phosphatase (PAP): evaluation by RNA blot analyses. Biochimica et Biophysica Acta 1048 72-77.

Song RX, Zhang Z \& Santen RJ 2005 Estrogen rapid action via protein complex formation involving ERalpha and Src. Trends in Endocrinology and Metabolism 16 347-353.

Stevenson LE \& Frackelton AR Jr 1998 Constitutively tyrosine phosphorylated p52 Shc in breast cancer cells: correlation with ErbB2 and p66 Shc expression. Breast Cancer Research and Treatment 49 119-128.

Stevenson LE, Ravichandran KS \& Frackelton AR Jr 1999 Shc dominant negative disrupts cell cycle progression in both G0-G1 and G2-M of ErbB2-positive breast cancer cells. Cell Growth and Differentiation 10 61-71.

Stewart LV, Lyles B, Lin MF \& Weigel NL 2005 Vitamin D receptor agonists induce prostatic acid phosphatase to reduce cell growth and HER-2 signaling in LNCaPderived human prostate cancer cells. Journal of Steroid Biochemistry and Molecular Biology 97 37-46.
Stracke ML, Engel JD, Wilson LW, Rechler MM, Liotta LA \& Schiffmann E 1989 The type I insulin-like growth factor receptor is a motility receptor in human melanoma cells. Journal of Biological Chemistry 264 21544-21549.

Sundaresan M, Yu ZX, Ferrans VJ, Sulciner DJ, Gutkind JS, Irani K, Goldschmidt-Clermont PJ \& Finkel T 1996 Regulation of reactive-oxygen-species generation in fibroblasts by Rac1. Biochemical Journal 318 379-382.

Taylor WR, Greenberg AH, Turley EA \& Wright JA 1993 Cell motility, invasion, and malignancy induced by overexpression of K-FGF or bFGF. Experimental Cell Research 204 295-301.

Thomas D \& Bradshaw RA 1997 Differential utilization of ShcA tyrosine residues and functional domains in the transduction of epidermal growth factor-induced mitogen-activated protein kinase activation in 293T cells and nerve growth factor-induced neurite outgrowth in PC12 cells. Identification of a new Grb2.Sos1 binding site. Journal of Biological Chemistry 272 22293-22299.

Trinei M, Giorgio M, Cicalese A, Barozzi S, Ventura A, Migliaccio E, Milia E, Martin-Padura I, Raker VA, Maccarana M et al. 2002 A p53-p66Shc signalling pathway controls intracellular redox status, levels of oxidation-damaged DNA and oxidative stress-induced apoptosis. Oncogene 30 3872-3878.

Unni E, Sun S, Nan B, McPhaul MJ, Cheskis B, Mancini MA \& Marcelli M 2004 Changes in androgen receptor nongenotropic signaling correlate with transition of LNCaP cells to androgen independence. Cancer Research 64 7156-7168.

Velverde MA, Rojas P, Amigo J, Cosmelli D, Orio P, Bahamonde MI, Mann GE, Vergara C \& Latorre R 1999 Acute activation of Maxi-K channels (hSlo) by estradiol binding to the beta subunit. Science 285 1929-1931.

Veeramani S \& Lin MF 2007 Role of reactive oxygen species in carcinogenesis. In Redox Biochemistry, pp 212-218. Ed R Banarjee. New Jercy: John Wiley \& Sons Inc.

Veeramani S, Yuan TC, Chen SJ, Lin FF, Petersen JE, Shaheduzzaman S, Srivastava S, MacDonald RG \& Lin MF $2005 a$ Cellular prostatic acid phosphatase: a protein tyrosine phosphatase involved in androgen-independent proliferation of prostate cancer. Endocrine-Related Cancer 12 805-822.

Veeramani S, Igawa T, Yuan TC, Lin FF, Lee MS, Lin JS, Johansson SL \& Lin MF $2005 b$ Expression of p66(Shc) protein correlates with proliferation of human prostate cancer cells. Oncogene 24 7203-7212.

Veeramani S, Yuan TC, Lin FF \& Lin MF 2008 Mitochondrial redox signaling by p66Shc is involved in regulating androgenic growth stimulation of human prostate cancer cells. Oncogene 27 5057-5068.

Ventura A, Luzi L, Pacini S, Baldari CT \& Pelicci PG 2002 The p66Shc longevity gene is silenced through epigenetic modifications of an alternative promoter. Journal of Biological Chemistry 277 22370-22376. 
Ventura A, Maccarana M, Raker VA \& Pelicci PG 2004 A cryptic targeting signal induces isoform-specific localization of p46Shc to mitochondria. Journal of Biological Chemistry 279 2299-2306.

Wary KK, Mainiero F, Isakoff SJ, Marcantonio EE \& Giancotti FG 1996 The adaptor protein Shc couples a class of integrins to the control of cell cycle progression. Cell 87 733-743.

Wary KK, Mariotti A, Zurzolo C \& Giancotti FG 1998 A requirement for caveolin-1 and associated kinase Fyn in integrin signaling and anchorage-dependent cell growth. Cell 94 625-634.

Webster MA, Hutchinson JN, Rauh MJ, Muthuswamy SK, Anton M, Tortorice CG, Cardiff RD, Graham FL, Hassell JA \& Muller WJ 1998 Requirement for both Shc and phosphatidylinositol $3^{\prime}$ kinase signaling pathways in polyomavirus middle T-mediated mammary tumorigenesis. Molecular and Cellular Biology 18 2344-2359.

Weigel NL 1996 Steroid hormone receptors and their regulation by phosphorylation. Biochemical Journal 319 657-667.

Weigel NL \& Moore NL 2007 Kinases and protein phosphorylation as regulators of steroid hormone action. Nuclear Receptor Signaling 5 e005.

Wong CW, McNally C, Nickbarg E, Komm BS \& Cheskis BJ 2002 Estrogen receptor-interacting protein that modulates its nongenomic activity-crosstalk with Src/Erk phosphorylation cascade. PNAS 99 14783-14788.
Xie Y \& Hung MC 1996 p66Shc isoform down-regulated and not required for HER-2/neu signaling pathway in human breast cancer cell lines with HER-2/neu overexpression. Biochemical and Biophysical Research Communications 221 140-145.

Yoshida S, Masaki T, Feng H, Yuji J, Miyauchi Y, Funaki T, Yoshiji H, Matsumoto K, Uchida N, Watanabe S et al. 2004 Enhanced expression of adaptor molecule p46 Shc in nuclei of hepatocellular carcinoma cells: study of LEC rats.

International Journal of Oncology 25 1089-1096.

Yuan TC, Lin FF, Veeramani S, Chen SJ \& Earp HS 2007 3rd \& Lin MF 2007 ErbB-2 via PYK2 upregulates the adhesive ability of androgen receptor-positive human prostate cancer cells. Oncogene 26 7552-7559.

Zaccagnini G, Martelli F, Fasanaro P, Magenta A, Gaetano C, Di Carlo A, Biglioli P, Giorgio M, Martin-Padura I, Pelicci PG et al. 2004 p66ShcA modulates tissue response to hindlimb ischemia. Circulation 15 2917-2923.

Zheng DQ, Woodard AS, Fornaro M, Tallini G \& Languino LR 1999 Prostatic carcinoma cell migration via alpha(v)beta3 integrin is modulated by a focal adhesion kinase pathway. Cancer Research 59 1655-1664.

Zhou MM, Ravichandran KS, Olejniczak EF, Petros AM, Meadows RP, Sattler M, Harlan JE, Wade WS, Burakoff SJ \& Fesik SW 1995 Structure and ligand recognition of the phosphotyrosine binding domain of Shc. Nature 378 584-592. 